\title{
Covid-19 Disrupts India's March towards Making Her Children Thrive and Transform
}

\author{
Geeta Chopra \\ Associate Professor, University of Delhi \\ DOI: 10.29322/IJSRP.10.10.2020.p10627 \\ http://dx.doi.org/10.29322/IJSRP.10.10.2020.p10627
}

\begin{abstract}
When the pandemic hit the world, everyone was relieved a bit that at least, the virus seemed to have a limited direct impact on children. But no one had anticipated the indirect effect the pandemic will have on children. This paper explores the impact of Covid 19 on infant and child mortality, child nutrition, schooling and child protection issues. It draws attention to the already worrisome pre-covid statistics on these parameters in India, and why one can expect things to go worse. Some solutions for remediation are also presented.
\end{abstract}

INDEX TERMS: Covid-19, under5mortality, maternal mortality, child protection, child labour

\section{INTRODUCTION}

This article brings to attention the plight of children from poor households from low income countries during the covid-19 pandemic.

The right to life with dignity is an inalienable right under the Constitution of India and the International Convention on Civil and Political Rights, 1966 that India has ratified. India ratified the UNCRC in 1992 and the obligations to ensure children's rights under the UNCRC also remain [1]. Child Rights journey is to make children survive, thrive and transform. It is a journey to make sure that all children:

- Have adequate food and healthcare services which help in their survival

- Attend schools and anganwadis where they get opportunities to learn and to develop their faculties and skills

- Are safe and protected from violence

- Have their best interests protected

- Have a say in decisions that affect their lives [2]

When the pandemic hit the world, everyone was relieved by the fact that the virus seemed to have a limited direct impact on children. In fact, the world statistics on Corona fatality by age showed zero deaths in the 0-9 years age group. But the world had not imagined the indirect effect the pandemic will have on.

The march of nations to achieve this has been delayed and disrupted due to the Covid pandemic. It is now believed that the progress made by nations in last 5-10 years to bring down the child and maternal mortality figures and those on protection parameters like child labour and abuse, is going to be wiped out [3].

India has child population of 472 million, of which, it is estimated that 40 million from poor families have been impacted by covid lockdown [4]. Childhoods have been threatened due to covid 19 and the impact is disproportionately high on children from poor households in low income countries. The marginalized groups of children like, children of migrant workers, street children, children living in institutions, the homeless, those living in abusive conditions with high risk of violence, children from rural or far flung areas who are now out of school or have been hit by disruption of health and nutrition services offered by the government, are badly hit. Let's discuss how children have been impacted by Covid-19.

\section{MATERNAL AND INFANT MORTALITY}

Based on a study by Timothy Robertson et al in Lancet [5] it is estimated in 118 low- and middle-income countries globally, 6000 additional child deaths per day are expected, which would be an additional 1.2 million under-five deaths in just six months. This would be due to reductions in routine health service coverage levels and an increase in child wasting, malnutrition, 
disruption of nutrition services, disruption of medical and food supply chains and health workers engaged in corona related work across the country.

The first comprehensive estimate of district-level trends of child mortality in India published in The Lancet and EClinicalMedicine, stated that if the trends observed up to 2017 were to continue, India would meet the SDG 2030 under-5 Mortality Rate (U5MR) target [6]. The study stated that the under- five Mortality Rate (U5MR) dropped in India since 2000 by 49 per cent. There were 1.04 million under-five deaths in India in 2017, while in 2000, there were 2.24 million under-five deaths. Now, with Covid pandemic, UNICEF estimates 440,000 children will be affected in South Asia over the next six months of which as many as 3,00,000 children would be in India alone owing to the lockdown, the pandemic continues to weaken health systems and disrupt routine services across the region," UNICEF said in a statement[7]. The gains in child mortality will be reversed due to thousands of additional child deaths.

Of 1.04 under 5 deaths in India in 2017, there were 0.57 million neonatal deaths in 2017, down from 1.02 million neonatal deaths in 2000. The NMR has dropped by 38 per cent from $2000-2017$. Now, this progress made gets negated. As per estimates of UNICEF, 20 million babies are expected to be born in India between March-December 2020 [3, 8]. In pre-covid times, pregnant women from across the country in India from poor households visited anganwadis and PHC to avail ante-natal check ups three times during pregnancy (more than 50\% women got all ANC checkups done). During these ANC checkups, regular monitoring of weight was done, blood pressure checked and routine urine and blood test done. Pregnant women were given Iron and Folic acid tablets along with Calcium. These women also received supplementary nutrition from the AWCs along with nutrition counselling. They received two shots of tetanus toxoid vaccination. The TT injections were a big intervention in preventing neonatal tetanus and helped in reducing neonatal and maternal mortality. As is clear, the services at the anganwadis and $\mathrm{MCH}$ centres got disrupted during covid. Additionally, rather than attending to their routine health care duties at AWCs and MCH centres, health functionaries were being involved in emergency Covid duties like, taking temperature, quarantine centre management and contact tracing etc.

Furthermore, due to lockdown and transport being unavailable[3], it became a challenge for pregnant women to reach health facilities on time for child birth. As per UNICEF [9], the rate of institutional deliveries in India was 79\% and Maternal Mortality ratio was 145. Covid is likely to decrease institutional deliveries further. Lowering of institutional deliveries will have a negative bearing on neonatal and infant survival. When an infant is delivered at an institution, she is weighed first and then she receives BCG, Oral polio vaccine and Hepatitis-B vaccines at birth. If the child is premature or is of low birth weight, child is kept in nursery or a NICU, if needed. There is birth registration also done, so child becomes eligible for availing government facilities and services. As per NHFS-4, the birth registration rate was $80 \%$, which will most likely go down. It is quite obvious that a large number of newborns during covid times are going to miss on these important vaccinations, and access to many services, hence increasing mortality and morbidity.

With Covid happening, Timothy Roberts et al [5] estimate that the decline in healthcare would result in additional 39\% maternal deaths due to pregnancy \& child birth related causes in 6 months. With health facilities closed or offering emergency services only, the use of contraceptive is also likely to go down. So, we can expect an increase in unwanted births. We need urgent measures to contain child and maternal mortality!

\section{NUTRITION AND HEALTH}

UNICEF reports that 368 million children in 143 countries are unable to access meals from schools due to closure of schools [10]. If we look at the situation in India, with AWC closure, this regular source of daily

school closure, this too has got disrupted. This is going to directly impact the nutrition levels of children and in long term effect cognitive development, concentration and learning outcomes. As per NHFS-4 [11], in India 38\% children under 5 years who are stunted (height for age), 28\% wasted (weight for height) and 36\% underweight (weight for age). It is not hard to understand where further malnutrition levels are going to reach in the prevailing conditions.

The Immunization status of children in India as per NHFS-4 was - 62\% children (12-24 months) are fully immunized. WHO reports that covid 19 is going to lead to a spike in measles among young children as measles immunization has been suspended in 37 countries and will not be reaching $117 \mathrm{~m}$ children, missing out on life saving vaccination [12]. Millions of children are in danger of missing life-saving vaccines against measles [13], diphtheria and polio due to disruptions in immunization service. Polio vaccination campaigns have been suspended worldwide, setting back the decades-long effort to eliminate the virus, and to tackle recent outbreaks of the vaccine-derived virus in Africa, East Asia and the Pacific. 


\section{POVERTY}

Another factor worth getting the attention of the readers is spike in poverty. IMF expects 3\% fall in global income in 2020 due to lockdown and rising unemployment. Immediate loss of income often means families are less able to afford basics [14], including food and water, are less likely to access health care or education, and are more at risk of violence, exploitation and abuse.

As per Global multidimensional poverty index reported in 2018, India had 364 million people in poverty, of whom, 154 million are children [15]. As per Unicef Policy brief [16], an estimated 42-66 million children could fall into extreme poverty as a result of the crisis this year, adding to the estimated 386 million children already in extreme poverty in 2019.

\section{SCHOOL CLOSURE AND DIGITAL DIVIDE}

As per UNICEF Policy brief [16, 17], 188 countries have imposed countrywide school closures, affecting more than 1.5 billion children and youth. The potential losses that may accrue in learning for today's young generation, and for the development of their human capital, are hard to fathom. More than two-thirds of countries have introduced a national distance learning platform, but among low-income countries the share is only 30 percent. Before this crisis, almost one third of the world's young people were already digitally excluded.

\section{CHILD PROTECTION}

UN warns, first rise in child labour in 2 decades globally likely. WHY? IMF indicates a rise in extreme poverty globally from 84 $\mathrm{m}$ to $132 \mathrm{~m}$ people. As per estimates, $1 \%$ increase in poverty leads to $0.7 \%$ increase in Child Labour as the number of children getting back to labour force is likely to shoot up due to poverty. Further exacerbating factors for global rise in child labour are likely illness/unemployment of parents, separation of the child from parent due to migration, death of parents, and many such reasons will necessitate children to step in as a bread winner. Another major factor is that school closure is likely to spike child labour. Even when schools start, parents may not be able to pay for it. Child labour robs children of childhood, exposes them to abuse, violence and exploitation. This is a real crisis for the children of the world.

During the lockdown everyone has been told to stay home. But what about the street children? Where do they go during the lockdown? According to one estimate, Delhi alone has more than 70,000 street children, who continue to be invisible.

Studies also show that when parents are without a job or a means of subsistence, it leads to frustration, and this is commonly vented out on the weak and meek. So, Covid has put children 'at risk' of increased violence at home. Confinement at home makes children soft targets.

Covid has also closed down child protection services or they are partially functional. Safe spaces where children participated and spoke freely, like schools, are also shut down. When children are at facility/zonal based quarantine, that context also reduces the safety net for them as they may be separated from parents or coping with misery. Limited support is available to already vulnerable groups of children like street children, those in institutions, in conflict with law, on the move and abandoned children. In India, CHILDLINE received 4.6 lakh calls in 21 days of lockdown, 9,385 interventions made, of which $20 \%$ for child marriage, child abuse, trafficking, abandonment, child labour. Childline interventions also prevented 898 child marriages during this period.

\section{CONCLUSION}

FUTURE AND PRESTIGE OF THE COUNTRY IS AT STAKE- actions needed

This pandemic has exposed social and structural inequities and failure of the system to respond. I would like to highlight a few emergency actions that we need to take if we want to reclaim some childhoods.

DATA: An assessment of the situation of children as a result of the impact of COVID both in the short and long term and make such data available in the public domain. How many children have migrated to villages, how many are out of school, how many not receiving immunization/supplementary nutrition? Data is needed on home deliveries during this period? How many children are still in children's institutions, what is happening to the street children, trafficked children and homeless children? 
RESUME SERVICES: Antenatal check up, nutrition and nutrition supplements services through anganwadis and MCH centres for pregnant mothers should be resumed immediately. Institutional deliveries and attended births are absolutely to be restored to bring back some stability in neonatal deaths.

UTLIZE FUNDS: Funding for children is not cut, existing resources are effectively utilized and augmented where there is a shortfall, and flexibility in utilization of Central Government funding [1].

STATUTORY ENTITLEMENTS: Children and families receive their statutory entitlements to livelihood for adults, food, and supplementary nutrition, health, education, care and protection, and efforts are intensified to cover those currently outside the net of social protection [1].

START SCHOOLS: States should come with staggered opening of schools so that mid-day meals as well as learning opportunities for children are restored. Children, especially girls, children with disabilities and transgender children, are not pushed out of education, children of migrant families are enrolled and supported to continue their education wherever they are.

CHILD PROTECTION SERVICES: Local authorities and bodies ensure children are not exploited, physically/ sexually/ emotionally abused, trafficked for labour/ sexual exploitation/ other purposes, forcibly married, or discriminated against, or separated from their families. Core child protection services, service providers and authorities (Childine, JJBs, CWCs, DCPUs, SJPUs and police, Child Care Institutions, lawyers, frontline workers in CSOs/NGOs, counsellors) and Anganwadi workers are declared as 'essential' during any lockdown or declared emergency [1]. Systems for reporting violence against children are strengthened and accessible to all children, including children with disabilities, children living in CCIs, and children in police custody[1].

This is a clarion call for the children of India.

\section{REFERENCE LIST}

[1] HAQ. Rights of children in the time of covid-19 Policy Brief. 2020 retreived https://www.haqcrc.org/wpcontent/uploads/2020/07/rights-of-children-in-times-of-covid-19.pdf

[2] Chopra,G., Child Rights in India Challenges and Social Action, Springer (2015)

[3]. Chopra, G. COVID Has Undone Child Rights Progress. Here's What Govt Must Do. Retrieved from https://www.thequint.com/voices/opinion/covid-pandemic-child-protection-laws-lack-of-nutrition-anganwadi-centres-maternalhealth-child-abuse

[4]. Pandey, G. (2020) Coronavirus: The children struggling to survive India's lockdown retrieved from https://www.bbc.com/news/world-asia-india-52210888

[5]. Timothy Roberton et al (2020) Early estimates of the indirect effects of the COVID-19 pandemic on maternal and child mortality in low-income and middle-income countries: a modelling study. Retrieved from www.thelancet.com/lancetgh Published online May 12, 2020 retrieved from https://doi.org/10.1016/S2214-109X(20)30229-1

[6]. India State-Level Disease Burden Initiative Child Mortality Collaborators (2020) Subnational mapping of under-5 and neonatal mortality trends in India: the Global Burden of Disease Study 2000-17 retrieved from https://www.thelancet.com/journals/lancet/article/PIIS0140-6736(20)30471-2/fulltext

[7]. UNICEF (2020) As COVID-19 devastates already fragile health systems, over 440,000 additional children under five could die in the next six months in South Asia, without urgent action retrieved from https://www.unicef.org/rosa/press-releases/covid19-devastates-already-fragile-health-systems-over-440000-additional-children 
[8]. UNICEF (2020) Millions of pregnant mothers and babies born during COVID-19 pandemic threatened by strained health systems and disruptions in services retrieved from https://www.unicef.org/rosa/press-releases/millions-pregnant-mothers-andbabies-born-during-covid-19-pandemic-threatened

[9]. UNICEF (2019), State of World's Children.

[10]. UNICEF and WFP (2020) Futures of 370 million children in jeopardy as school closures deprive them of school meals retrieved from https://www.unicef.org/press-releases/futures-370-million-children-jeopardy-school-closures-deprive-them-schoolmeals

[11]. http://rchiips.org/nfhs/factsheet_NFHS-4.shtml

[12]. WHO (2020) More than 117 million children at risk of missing out on measles vaccines, as COVID-19 surges. retrieved from https://www.who.int/immunization/diseases/measles/statement_missing_measles_vaccines_covid-19/en/

[13] IANS (2020) Unicef warns over lack of life-saving vaccines for kids retrieved from https://newsd.in/unicef-warns-over-lackof-life-saving-vaccines-for-kids/

[14] Deen, T. World Risks Losing Entire Generation of Children, Nobel Laureates Warn. Retrieved from https://www.globalissues.org/news/2020/09/07/26799

[15]. University of Oxford (2018) Global MPI 2018 retrieved from https://ophi.org.uk/multidimensional-poverty-index/globalmpi-2018/

[16]. UNICEF (2020). . Children in monetary poor households and COVID-19 Technical note retrieved from https://data.unicef.org/resources/children-in-monetary-poor-households-and-covid-19/

[17]. PTI. COVID-19 could cause hundreds of thousands of additional child death: UN. Retreived from https://economictimes.indiatimes.com/news/international/world-news/covid-19-could-cause-hundreds-of-thousands-of-additionalchild-death-un/articleshow/75197118.cms

\section{AUTHOR:}

Geeta Chopra, Ph.D., Institute of Home Economics, University of Delhi. Email: drgeetachopra@gmail.com 